\title{
TESTING THE CORRELATION BETWEEN MEAN REVERSION PROCESS AND GREY SYSTEM THEORY FOR METAL PRICE FORECASTING
}

\author{
TEST KORELACIJE IZMEĐU PROCESA POVRATKA NA \\ SREDNJU VREDNOST I TEORIJE SIVOG SISTEMA U SVRHU \\ PROGNOZE CENE METALA
}

\author{
Gligorić Zoran ${ }^{1}$, Milojević Jelena ${ }^{1}$, Beljić Čedomir ${ }^{1}$
}

Received: May 14, 2014

Accepted: June 2, 2014

\begin{abstract}
There are typically many of variables, which are directly or indirectly associated with the value of underground mine project. Having the ability to plan for uncertainties of input variables is increasingly recognized as critical to longterm mining project success. Large capital intensive projects, such as those in the mineral resource industry, are often associated with diverse sources of both internal and external uncertainties. One of the most external influencing uncertainties is related to the future states of metal price. There are many methods which are applied to forecast the future metal prices, but Mean Reversion Process is one of the most applying methods. This paper analyzes the possibility of using of Grey System Theory to metal price forecasting by examining the correlation between results obtained by these two methods. Intra-class Correlation Coefficient is used as a measure of reliability.
\end{abstract}

Key words: metal price, uncertainty, Mean Reversion Process, Grey System Theory, Intra-class Correlation Coefficient

Apstrakt: Postoji veliki broj promenljivih, koje su direktno ili indirektno povezane sa vrednošću projekta podzemne eksploatacije. Sposobnost planiranja neodređenosti ulaznih promenljivih sve više se prepoznaje kao kritična za dugoročni uspeh projekta. Kapitalni projekti, kao što su rudarski, često su skopčani sa različitim izvorima i unutrašnjih i spoljašnjih neodređenosti. Jedna od najuticajnijih spoljašnjih neodređenosti povezuje se sa budućim cenama metala. Postoji veliki broj metoda koje se koriste sa procenu budućih cena metala, ali Proces povratka na srednju vrednost je metoda koja se najviše primenjuje. U ovom radu se analizira mogućnost primene Teorije sivog sistema za prognozu cene metala, istražujući korelaciju između rezultata koji su dobijeni primenom ove dve metode. Intra-klasni koeficijent korelacije koristi se kao mera pouzdanosti.

Ključne reči: cena metala, Proces povratka na srednju vrednost, Teorija sivog sistema, Intra-klasni koeficijent korelacije

\footnotetext{
${ }^{1}$ University of Belgrade - Faculty of Mining and Geology, Đušina 7, 11000 Belgrade, Serbia, e-mails: zoran.gligoric@rgf.bg.ac.rs; jelena.milojevic707@hotmail.com; cedomir.beljic@rgf.bg.ac.rs
} 


\section{INTRODUCTION}

Uncertainty in a mining project is commonly evaluated with respect to endogenous (internal) and exogenous (external) conditions. Internal conditions are those governed by the deposit and mining method itself, such as grade, ground conditions, workforce, management, schedule, equipment and infrastructure. External conditions are determined by outside considerations, such as market prices, environmental conditions, political risk, government policies, stakeholder issues, as well as community and industrial relations (Kazakidis and Scoble, 2003). The combined effect of market volatility and uncertainty about future commodity prices is posing higher risk to mining businesses across the globe. Estimating mineral project revenue is, indeed, a difficult and risky activity. Annual mine revenue is calculated by multiplying the number of units produced and sold during the year by the sales price per unit.

The market risks related to the commodity price are modelled with a special stochastic process, a mean reversion process. The mean reversion process has economic logic, for example, although the commodity prices have sensible short-term oscillations, they tend to revert back to a "normal" long-term equilibrium level.

Metal prices can be treated as a time series. A time series is a collection of data points which are generally sampled equally in time intervals. Time series prediction refers to the process by which the future values of a system is forecasted based on the information obtained from the past and current data points. In this paper we apply Grey system theory to forecast future values of metal price and obtained results we compare to values obtained by Mean reversion process. Intra-class Correlation Coefficient is used as a measure of reliability.

\section{METHODOLOGY OF TESTING}

\subsection{Mean reversion process (MRP)}

Estimating future metal prices is an exercise for which a high error of estimation invariably exists. The characteristically long preproduction periods of mining projects mean that their success will be determined by metal prices five to ten years in the future.

The market risks related to commodity price are modelled with a special stochastic process, a mean reversion process. The mean reversion process has economic logic, for example, although the commodity prices have sensible short-term oscillations, they tend to revert back to a "normal" long-term equilibrium level. The mean reversion evidence is reported in many studies. The past values of the changes in this risk factor help predict the future. We will use a model where the metal spot price is assumed to follow the stochastic process (Schwartz, 1997):

$$
d P=k(\ln \bar{P}-\ln P) P d t+\sigma P d W
$$

Let $x=\ln P$, applying Ito's Lemma allows the characterization of the log price by an Ornstein-Uhlenbeck stochastic mean reverting process:

$$
d x=k(\bar{x}-x) d t+\sigma d W
$$


with

$$
\bar{x}=\ln (\bar{P})-\frac{\sigma^{2}}{2 k}
$$

where $\bar{P}$ is the long-run equilibrium metal price, $k$ measures the speed of mean reversion to the long run mean $\log$ price $\bar{P}, d W$ is an increment to a standard Brownian motion and $\sigma$ refers to the price volatility rate. The metal price adjustment mechanism is accounted for by market forces. Suppose we observe that metal price jumps from $P_{1}$ to $P_{2}$ due to an unexpected event. Most market practitioners would agree that is highly probable that price will eventually return to its average level once the cause of the jump goes away. For similar reasons if the price falls from $P_{1}$ to $P_{2}$ due to overproduction we would expect the price to eventually rise as producers decrease supply. These expectations are intuitive in nature and are supported by our observations of metal current price behavior. Notice from equation (1) that the mean reversion component term is governed by the distance between the current price and the long-run equilibrium metal price as well as by the speed of mean reversion. If the current price is below the long-run equilibrium, the mean reversion component will be positive, resulting in an upward influence on the current price. Alternatively, if the current price is above the long-run equilibrium, the mean reversion component will be negative, thus exerting a downward influence on the current price. Over time, this results in a price path that drifts towards the long-run equilibrium, at a rate determined by the speed of mean reversion.

The correct discrete-time format for the continuous-time process of mean reversion is the stationary first order autoregressive process (Dixit and Pindyck, 1994), so the sample path simulation equation for $x_{t}$ is performed by using exact discrete-time expression:

$$
x_{t}=x_{t-1} \cdot e^{-k \Delta t}+\bar{x}\left(1-e^{-k \Delta t}\right)+N(0,1) \sigma \sqrt{\frac{1-e^{-2 k \Delta t}}{2 k}}
$$

where $\Delta t$ is the fixed time interval from time $t$ to $t+1$ and $N(0,1)$ is the normally distributed random variable. By substituting equation (4) to $P=e^{x}$, we have exact discrete-time equation for $P_{t}$, given by:

$$
P_{t}=\exp \left\{\ln \left(P_{t-1}\right) e^{-k \Delta t}+\left[\ln (\bar{P})-\frac{\sigma^{2}}{2 k}\right]\left(1-e^{-k \Delta t}\right)+N(0,1) \sigma \sqrt{\frac{1-e^{-2 k \Delta t}}{2 k}}\right\}
$$

In order to estimate the parameters of the mean reversion process, we run the following regression.

$$
d x_{t+1}=\beta_{o}+\beta_{1} x_{t}+\varepsilon
$$

where:

$\beta_{o}=k \bar{x} d t$ and $\beta_{1}=-k d t$. Hence, if we regress observation $d x$ against $x$, we can obtain estimates of $\beta_{o}$ and $\beta_{l}$.

$\sigma$ - the standard deviation from the regression.

The speed of mean reversion $k$ is the negative of the slope, while the long-run equilibrium $\bar{P}$ is the intercept estimate of that regression divided by the speed of mean reversion. Let $P=\left\{P_{t}, t=0, \ldots, T\right\}$ denote a price scenario with spot prices $P_{t}$, where $P_{t}$ 
is determined by equation (5). Figure 1 presents a sample paths of the metal price simulated using the above equation.

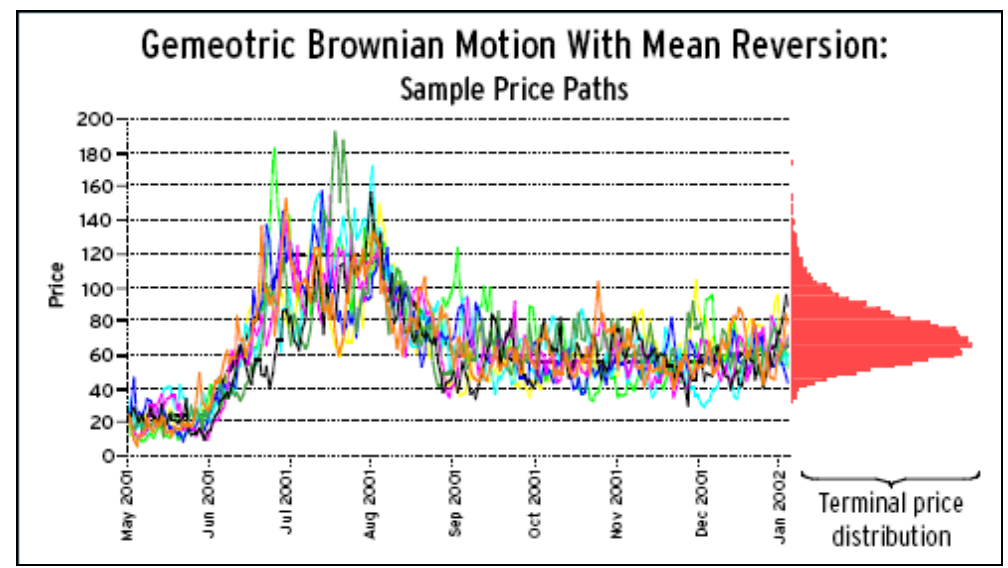

Figure 1 - Simulated metal prices (Blanco and Soronow, 2001)

\subsection{Grey system theory (GST)}

A time series is a collection of data points which are generally sampled equally in time intervals. Time series prediction refers to the process by which the future values of a system is forecasted based on the information obtained from the past and current data points. Generally, a pre-defined mathematical model is used to make accurate predictions (Kayacan et al. 2010). Grey system theory is an interdisciplinary scientific area that was first introduced by Deng (1982). The main task of grey system theory is to extract realistic governing laws of the system using available data. This process is known as the generation of the grey sequence (Liu and Lin, 1998).

In grey systems theory, $\operatorname{GM}(n, m)$ denotes a grey model, where $n$ is the order of the difference equation and $m$ is the number of variables. $\operatorname{GM}(1,1)$ model is the most widely used, pronounced as "Grey Model First Order One Variable". The GM $(1,1)$ model can only be used in positive data sequences (Deng, 1989).

Let consider a time sequence $P^{(o)}$ that denotes historical data of an metal price in USD/t (Figure 2),

$$
P^{(o)}=\left(p^{(o)}(1), p^{(o)}(2), \ldots, p^{(o)}(n)\right), \quad n \geq 4
$$

where $P^{(o)}$ is a non-negative sequence and $n$ is the sample size of the data.

The following procedures address the process of using $\operatorname{GM}(1,1)$ to make a one-step ahead prediction (Yang et al. 2012). 


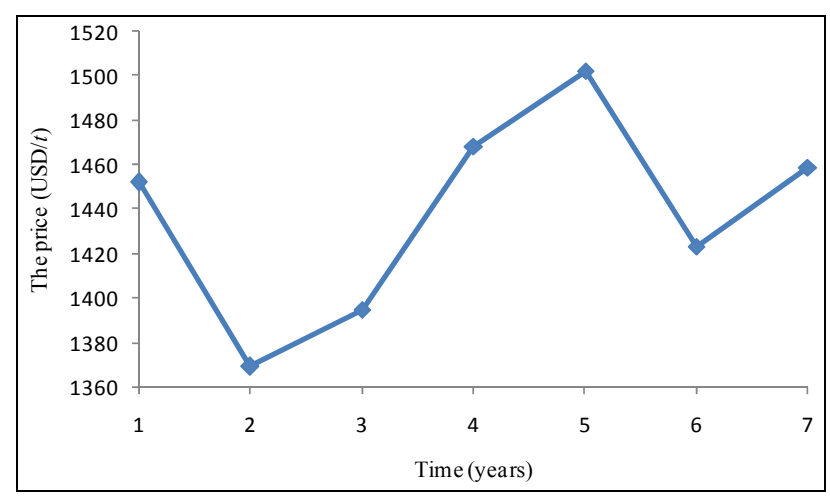

Figure 2 - The original data set

Step 1: Perform accumulated generating operation (AGO). The AGO is performed to the original time series or primitive sequence to weaken the tendency of data variation. Let $p^{(1)}(k)$ be the new time series generated by AGO, as listed in the following equation.

$$
P^{(1)}=\left(p^{(1)}(1), p^{(1)}(2), \ldots, p^{(1)}(n)\right)
$$

where

$$
P^{(1)}(k)=\sum_{i=1}^{k} p^{(o)}(i), \quad k=1,2, \ldots, n
$$

Note that the new series $p^{(1)}$ obtained from one-time AGO (1-AGO) has the property of monotonic increasing. Obviously, this monotonic property makes $p^{(1)}$ easier to be predicted than that in the original series $p^{(o)}$.

Step 2: Modeling with a differential equation. As the solution of first-order ordinary differential equations (ODE) has the same monotonic increasing property as the series derived from AGO, the model of $p^{(1)}$ can be approximate by a differential equation as follows:

$$
\frac{d p^{(1)}}{d t}+a p^{(1)}=b
$$

where $a$ and $b$ are model parameters need to be determined, called developing coefficient and grey input, respectively.

Step 3: Determine model parameters. The model parameters $a$ and $b$ can be estimated by introducing a new variable $z^{(1)}(k)$, called background value, in the following approximation model.

$$
p^{(o)}(k)+a z^{(1)}(k)=b, \quad k \geq 2
$$

where $z^{(1)}(k)$ is defined as: 


$$
\begin{aligned}
z^{(1)}(k) & =\left(z^{(1)}(2), z^{(1)}(3), \ldots, z^{(1)}(n)\right)= \\
& =\alpha p^{(1)}(k)+(1-\alpha) p^{(1)}(k-1), \quad k=2,3, \ldots, n
\end{aligned}
$$

In conventional grey models, the parameter $\alpha$ is set to 0.5 and can be expressed as:

$$
z^{(1)}(k)=0.5 p^{(1)}(k)+0.5 p^{(1)}(k-1)
$$

Now, $a$ and $b$ can be estimated using the least-square technique described as follows. At first, we rearrange equation (12) in the form of simultaneous equations:

$$
\left\{\begin{array}{c}
p^{(o)}(2)+a z^{(1)}(2)=b \\
p^{(o)}(3)+a z^{(1)}(3)=b \\
\vdots \\
p^{(o)}(n)+a z^{(1)}(n)=b
\end{array}\right.
$$

Then, the matrix form of the equation (14) is described as:

$$
\left[\begin{array}{c}
p^{(o)}(2) \\
p^{(o)}(3) \\
\vdots \\
p^{(o)}(n)
\end{array}\right]=\left[\begin{array}{cc}
-z^{(1)}(2) & 1 \\
-z^{(1)}(3) & 1 \\
\vdots & \vdots \\
-z^{(1)}(n) & 1
\end{array}\right] \cdot\left[\begin{array}{l}
a \\
b
\end{array}\right]
$$

Let

$$
B=\left[\begin{array}{cc}
-z^{(1)}(2) & 1 \\
-z^{(1)}(3) & 1 \\
\vdots & \vdots \\
-z^{(1)}(n) & 1
\end{array}\right]
$$

and

$$
Y=\left[\begin{array}{c}
p^{(o)}(2) \\
p^{(o)}(3) \\
\vdots \\
p^{(o)}(n)
\end{array}\right]
$$

By applying the Moore-Penrose pseudo-inverse, parameters $a$ and $b$ can be determined as follows:

$$
\left[\begin{array}{l}
a \\
b
\end{array}\right]=\left(B^{T} \cdot B\right)^{-1} \cdot B^{T} \cdot Y
$$

Step 4: Estimate data points in $p^{(1)}$ space. As the initial condition of equation (10) is $p^{(1)}(1)=p^{(o)}(1)$, once the model parameters are determined, the solution of the equation (10) can be obtained as follows: 


$$
\hat{p}^{(1)}(k)=\left(p^{(o)}(1)-\frac{b}{a}\right) \cdot e^{-a(k-1)}+\frac{b}{a}
$$

where $\hat{p}^{(1)}(k)$ is defined as the estimated value of $p^{(1)}(k)$. By substituting $k$ with $n+a$ into equation (19), the one-step ahead prediction in $p^{(1)}$ space can be obtained as follows:

$$
\hat{p}^{(1)}(n+1)=\left(p^{(o)}(1)-\frac{b}{a}\right) \cdot e^{-a \cdot n}+\frac{b}{a}
$$

Step 5: Transform estimated AGO series back to $p^{(o)}$ space. This step is to transform the predicted value in $p^{(1)}$ back to $p^{(o)}$ space by performing the operation of inverse AGO (IAGO) using following equation:

$$
\hat{p}^{(o)}(k+1)=\hat{p}^{(1)}(k+1)-\hat{p}^{(1)}(k)
$$

\subsection{Intra-class correlation coefficient}

Intra-class correlation coefficients (ICC) are commonly used in different research fields as a measure of reliability. There are three basic classes of intra-class correlation coefficients, which they term Case 1, Case 2 and Case 3. In each case $n$ randomly chosen targets are rated by $k$ raters, with distinction that for Case 1 each target is rated by different raters, for Case 2 the same raters rate each target and for Case 3 all possible raters rate each target (Doros and Lew, 2010).

Intra-class correlation is the strength of a linear relationship between subjects belonging to the same class or the same subgroup or the same family. In the agreement setup, the two measurements obtain on the same subject by two observers or two methods is a subgroup. If they agree, the intra-class correlation will be high. This method of assessing an agreement was advocated by Lee et al. (1989).

Statistically, intra-class correlation is that part of the total variance that is accounted for by the difference in the paired measurements obtained by two methods (Indrayan, 2013). That is:

$$
r=\frac{\sigma_{M}^{2}}{\sigma_{M}^{2}+\sigma_{e}^{2}}
$$

whereby:

$\sigma_{M}^{2}$ - the variance between methods, and

$\sigma_{e}^{2}$ - the error variance.

For grading of the strength of agreement, the cutoffs shown in Table 1 can be used. 
Table 1 - The strength of agreement

\begin{tabular}{|c|c|}
\hline Intra-class correlation & Strength of agreement \\
\hline \hline$<0.25$ & Poor \\
\hline $0.25-0.50$ & Fair \\
\hline $0.50-0.75$ & Moderate \\
\hline $0.75-0,90$ & Good \\
\hline$>0.90$ & Excellent \\
\hline
\end{tabular}

\subsection{Testing the correlation between MRP and GST}

Once the simulations $P_{t}^{S}, s=1,2, \ldots, S ; t=1,2, \ldots, T$ (5), have been obtained, they can be used to estimate the distribution of the future metal price for every year of project time. By this way, we obtain the forecasted time series of metal price as follows:

$$
P_{t}=\left\{p_{1}, p_{2}, \ldots, p_{t}\right\}, \quad t=1,2, \ldots, T
$$

where $p_{t}=E\left(P_{t}^{S}\right)$ is expected value of metal price for every year of project time. as follows:

According to equation (21) we obtain the forecasted time series of metal price

$$
P_{t}^{(o)}=\left\{p_{1}^{(o)}, p_{2}^{(o)}, \ldots, p_{t}^{(o)}\right\}, \quad t=1,2, \ldots, T
$$

Consider a data set consisting of $T$ paired data values $\left(p_{t, M R P}, p_{t, G S T}^{(o)}\right)$, for $t=1,2, \ldots, T$. The intraclass correlation coefficient is as follows:

$$
\begin{aligned}
\sigma_{M}^{2} & =\frac{\sum\left(\sum p\right)^{2}}{T}-\frac{\left(\sum \sum p\right)^{2}}{2 T} \\
\sigma_{e}^{2} & =\sum \sum p^{2}-\frac{\sum\left(\sum p\right)^{2}}{T} \\
r= & \frac{\frac{\sum\left(\sum p\right)^{2}}{T}-\frac{\left(\sum \sum p\right)^{2}}{2 T}}{\frac{\sum\left(\sum p\right)^{2}}{T}-\frac{\left(\sum \sum p\right)^{2}}{2 T}+\sum \sum p^{2}-\frac{\sum\left(\sum p\right)^{2}}{T}}
\end{aligned}
$$

\section{NUMERICAL EXAMPLE}

Numerical example shows the examination related to the price of zinc metal. The input parameters required for the testing the correlation between MRP and GST are given in the Table 2. Note, the situation is hypothetical and the numbers used are in to permit calculation. 
Table 2 - Input parameters

\begin{tabular}{|c|c|c|c|c|c|}
\hline Year & 2009 & 2010 & 2011 & 2012 & 2013 \\
\hline Metal price $[\$ / \mathrm{t}]$ & 1658 & 2160 & 2195 & 1950 & 1910 \\
\hline \multicolumn{2}{|l|}{ Parameters of MRP } & & & & \\
\hline The long-run equilibrium $(\bar{P})$ & 2046 & & & & \\
\hline The price volatility rate $\sigma$ & 0.08377 & & & & \\
\hline The speed of mean reversion $k$ & 1.14654 & & & & \\
\hline The fixed time interval $\Delta t$ & 1 year & & & & \\
\hline Number of simulation $S$ & 500 & & & & \\
\hline Time horizon $T$ & 8 years & & & & \\
\hline Spot value $P(t=0)[\$ / \mathrm{t}]$ & 2000 & & & & \\
\hline \multicolumn{2}{|l|}{ Parameters of GST } & & & & \\
\hline$a$ & 0.048106 & & & & \\
\hline$b$ & 2337.41 & & & & \\
\hline Time horizon $T$ & 8 years & & & & \\
\hline
\end{tabular}

Mean reversion price scenario is defined as follows:

$$
\begin{aligned}
P_{t}= & \exp \left\{\ln \left(P_{t-1}\right) e^{-1.14654}+\left[\ln (\bar{P})-\frac{0.08377^{2}}{2 \times 1.14654}\right]\left(1-e^{-1.14654}\right)+\right. \\
& \left.+N(0,1) \cdot 0.08377 \sqrt{\frac{\left(1-e^{-2 \times 1.14654}\right)}{2 \times 1.14654}}\right\}
\end{aligned}
$$

Grey system theory scenario is defined as follows:

$$
\hat{p}^{(1)}(t+1)=\left(1658-\frac{2337.41}{0.048106}\right) e^{-0.048106 t}+\frac{2337.41}{0.048106}
$$

Forecasted values of the zinc metal price for the period 2014-2021 is represented in the Table 3 and Figure 3.

Table 3 - Forecasted values of the zinc metal price 2014-2021

\begin{tabular}{|c||c|c|}
\hline Year & MRP & GST \\
\hline \hline $\mathbf{2 0 1 4}$ & 2150 & 1818 \\
\hline $\mathbf{2 0 1 5}$ & 2081 & 1733 \\
\hline $\mathbf{2 0 1 6}$ & 2058 & 1652 \\
\hline $\mathbf{2 0 1 7}$ & 2049 & 1574 \\
\hline $\mathbf{2 0 1 8}$ & 2052 & 1500 \\
\hline $\mathbf{2 0 1 9}$ & 2048 & 1430 \\
\hline $\mathbf{2 0 2 0}$ & 2043 & 1362 \\
\hline $\mathbf{2 0 2 1}$ & 2042 & 1298 \\
\hline
\end{tabular}




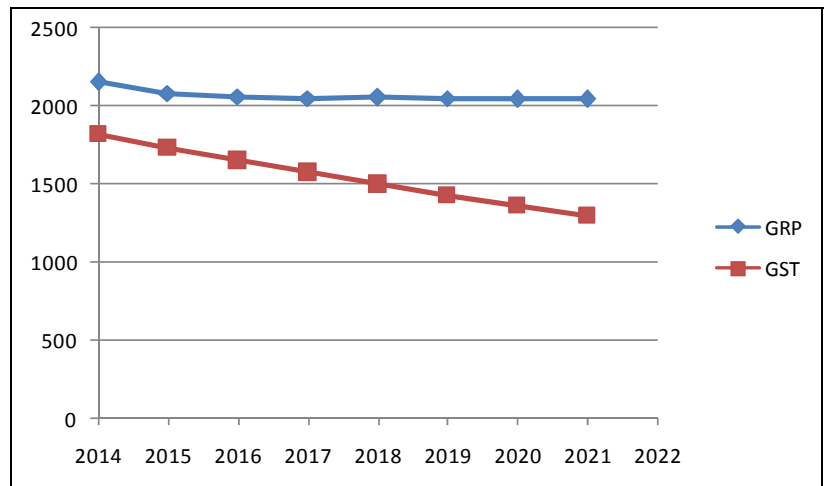

Figure 3 - Forecasted values of zinc metal price 2014-2021

4.

Calculation of the intra-class correlation coefficient is represented in the Table

Table 4 - Calculation of ICC

\begin{tabular}{|c|c|c|c|}
\hline Year & MRP & GST & \\
\hline 2014 & 2150 & 1818 & \\
\hline 2015 & 2081 & 1733 & \\
\hline 2016 & 2058 & 1652 & \\
\hline 2017 & 2049 & 1574 & \\
\hline 2018 & 2052 & 1500 & \\
\hline 2019 & 2048 & 1430 & \\
\hline 2020 & 2043 & 1362 & \\
\hline 2021 & 2042 & 1298 & \\
\hline$T$ & 8 & 8 & $2 T=16$ \\
\hline$\sum p$ & 16523 & 12367 & $\sum \sum p=28890$ \\
\hline $\bar{p}$ & 2065.37 & 1545.87 & $\sum \sum p / 2 T=1805.62$ \\
\hline$\sum p^{2}$ & 34135447 & 19349741 & $\sum \sum p^{2}=53485188$ \\
\hline$\left(\sum p\right)^{2} / T$ & 34126191 & 19117836 & $\sum\left(\sum p\right)^{2} / T=53244027$ \\
\hline$\sigma_{M}^{2}$ & 49901203 & $\sigma_{e}^{2}$ & 241160 \\
\hline \multicolumn{2}{|c|}{$r=\frac{\sigma_{M}^{2}}{\sigma_{M}^{2}+\sigma_{e}^{2}}$} & \multicolumn{2}{|r|}{0.99519} \\
\hline
\end{tabular}

According to the Table 1, correlation between MRP and GST is excellent.

\section{CONCLUSION}

Estimating future metal prices is an exercise for which a high error of estimation invariably exists. The characteristically long preproduction periods of mining projects mean that their success will be determined by metal prices five to ten 
years in the future. Having the ability to plan for uncertainties of metal prices is increasingly recognized as critical to long-term mining project success. For this purpose Grey system theory is used as method to forecast the future values of the zinc metal price. Intra-class coefficient of correlation between MRP and GST, as a measure of reliability, shows that GST method can be used as forecasting method. Values obtained by GST have more restrictive influence on the project evaluation process than values obtained by MRP, that is GST is much more rigid.

\section{REFERENCES}

[1] BLANCO, C. and SORONOW, D. (2001), Mean Reverting Processes Energy Price Processes Used For Derivatives Pricing \& Risk Management. Commodities Now, 5(2), pp.68-72.

[2] DENG, J.L. (1982) Control problems of grey system. Systems and Control Letters, 1(5), pp.211-215.

[3] DENG, J.L. (1989) Introduction to grey system theory. The Journal of Grey System, 1, pp.1-24.

[4] DIXIT, A.K. and PINDYCK, R.S. (1994) Investment under Uncertainty. Princeton: Princeton University Press.

[5] DOROS, G. and LEW, R. (2010) Design Based on Intra-Class Correlation Coefficients. American Journal of Biostatistics, 1 (1), pp.1-8.

[6] INDRAYAN, A. (2013), Clinical Agreement in Quantitative Measurments: Limits of Disagreement and the Intraclass Correlation. In: DOI, S.A.R. and WILLIAMS, G.M. (eds.), Methods of Clinical Epidemiology. Berlin Heilderberg: Springer-Verlag, pp.17-27.

[7] KAYACAN, E. et al. (2010), Grey system theory-based models in time series prediction. Expert Systems with Applications, 37, pp.1784-1789.

[8] KAZAKIDIS, V.N. and SCOBLE, M. (2003), Planning for flexibility in underground mine production system. SME Mining Engineering Journal, 55(8), pp.16-21.

[9] LEE, J. et al. (1989) Statistical evaluation of agreement between two methods for measuring a quantitative variable. Comput. Biol. Med., 19, pp.61-70.

[10] LIU, S. and LIN, Y. (1998), An introduction to grey systems: Foundations, Methodology and Applications. New York: IIGSS Academic Publisher.

[11] SCHWARTZ, E. (1997), The Stochastic Behaviour of Commodity Prices: Implications for Valuation and Hedging. The Journal of Finance, 52(3), pp.923-973.

[12] YANG, Y.W. et al. (2012) A Fuzzy-Grey Model for Non-stationary Time series Prediction. Applied Mathematics and Information Sciences, 6(2S), pp.445S-451S. 